\title{
EDUKASI PERILAKU HIDUP BERSIH DAN SEHAT (PHBS) UNTUK MENCEGAH PENULARAN VIRUS CORONA (COVID-19) DI RT 031 KELURAHAN LOK BAHU KECAMATAN SUNGAI KUNJANG SAMARINDA
}

\author{
Sister Sianturi ${ }^{1}$, Habel Roy Sulo ${ }^{2}$, dan Sumarti binti Amrin ${ }^{3}$ \\ Program Studi S-1 Farmasi, STIKES Dirgahayu Samarinda \\ J1. Pasundan No.21 Kelurahan Jawa, Kecamatan Samarinda Ulu, Kota Samarinda 75122 \\ e-mail: sianturisister16@gmail.com
}

\begin{abstract}
ABSTRAK
Virus Corona (COVID-19) adalah jenis penyakit yang menyebabkan gangguan pada saluran pernafasan baik ringan maupun akut. Virus ini merupakan virus yang penularannya sangat cepat sehingga untuk mengatasi penularan ini diperlukan edukasi kepada setiap masyarakat untuk mengetahui cara pencegahan penularan virus. Kegiatan ini dilakukan untuk memberi edukasi kepada masyarakat khususnya di RT 031 Kelurahan Lok Bahu Samarinda terkait penularan virus Corona dan cara mencegah penularannya sebagai upaya untuk melindungi diri sendiri dan keluarga serta orang lain dari penularan virus Corona. Materi yang disampaikan dalam kegiatan ini adalah: pengenalan virus COVID-19, bagaimana proses penularan, penggunaan masker yang baik, demonstrasi cara cuci tangan yang baik dan benar, bagaimana cara untuk akses informasi dan berita yang akurat sehingga tidak mudah menyebarkan berita yang tidak benar, dan penerapan pola hidup bersih dan sehat untuk mencegah penularan seperti konsumsi makanan bersih dan sehat dan konsumsi suplemen makanan untuk meningkatkan daya tahan tubuh. Edukasi dilakukan dengan metode ceramah, diskusi, tanya jawab, dan demonstrasi. Evaluasi dilakukan dengan menggunakan lembar angket untuk mengetahu pengetahuan peserta sebelum dan setelah diadakan edukasi. Hasil kegiatan menunjukkan bahwa edukasi ini dapat meningkatkan pengetahuan peserta yang dilihat dari presentase pengetahuan peserta sebelum diberikan edukasi sebesar 50,58\% yang kemudian meningkat menjadi $89,48 \%$ setealah diberikan edukasi.
\end{abstract}

Kata Kunci: COVID-19, Edukasi, PHBS, Virus Corona,

\begin{abstract}
Corona Virus (COVID-19) is a type of diasease that causes respiratory problems, both mild and acute. This virus spreading so rapidly so that to overcoma this transmission education is needed to everyone to findout the prevention of this virus transmission. The objective of this activity is to provide education to public especially at RT 031 Lok Bahu Samarinda regarding the transmission of Corona Virus and how to prevent transmission as an effort to protect theirself, their families, and other from Corona Virus transmission. The methode used in this activity is prensentation the materials inculeded: the introduction of Corona Virus, transmission process, how use mask properly, demonstration how wash hand properly, how to acces accurate information about Corona Virus and not easy to spread wrong news or issue, and how to have healthy lifestyle to prevent transmission such us consume a clean and healthy foods and some supplements to increase immune system or immunebooster. Education is carried out by means of lectures, discussion, question and answer session, and demonstration. Evaluation is carried out by using questionnnaire to find out the knowledge of the participants before and after the education held. The result of the activity show increasing knowledge of participant as seen from the percentage knowledge of participants before given education 50,58\% to 89,48\% after given education.
\end{abstract}

Key Words: Corona Virus, COVID-19, Education, Healthy Lifestyle

\section{PENDAHULUAN}

Virus Corona (COVID-19) adalah virus yang termasuk dalam family Coronavirus yang menyerang manusia maupun hewan. Virus ini menyebabkan adanya gangguan pada sistem pernafasan yang dapat dimanifestasikan dengan flu biasa sampai dengan penyakit yang lebih berat seperti Middle East Respiratory
Syndrome (MERS), dan sindrom pernafasan yang akut atau dikenal dengan Severa Acute Respiratory Syndrome (SARS).

COVID-19 adalah jenis penyakit yang belum pernah diidentifikasi sebelumnya pada manusia. Cara penularan virus ini adalah melalui 
percikan (droplet) saluran pernafasan dan kontak langsung dengan penderita. Percikan atau droplet ini bisa menjadi media penularan saat penderita batuk atau bersin sehingga percikan saluran pernafasan pembawa virus ini akan berpindah ke orang lain. Seseorang yang berada dalam radius $1 \mathrm{~m}$ dengan penderita beresiko terpapar percikan saluran pernafasan yang kemudian akan menularkan virus kepada orang tersebut. Percikan ini juga bisa jatuh ke permukaan benda dan akan beresiko menularkan virus pada percikan tersebut ketika ada orang lain yang menyentuh benda tersebut (WHO, 2020).

Virus Corona mulai menyebar ke Indonesia sejak bulan Maret 2020. Upaya mencegah penularan virus ini bukan hanya tanggung jawab pemerintah tetapi diperlukan peran dari semua eleman masyarakat karena menyangkut kesadaran dari semua lapisan masyarakat untuk turut serta dalam meindungi diri sendiri, keluarga, dan semua masyarakat dari penularan virus Corona.

Upaya pemerintah dalam menanggulangi wabah adalah dengan memangkitkan kesadaran masyarakat untuk bersama sama menanggulangi penyebaran virus ini tetapi belum semua masyarakat mengetahui upaya upaya ini karena kurangnya sosialisasi ke semua lapisan masyarakat, kurangnya pengetahuan masyarakat akan upaya pencegahan penularan virus, dan beberapa masyarakat yang belum memiliki kesadaran sendiri untuk mematuhi anjuran pemerintah.

Upaya dalam menanggulangi penyebaran virus Corona ini pemerintah telah menganjurkan untuk menggunakan masker, menjaga jarak aman saat berinteraksi dengan orang lain, mencuci tangan dengan sabun, dan menerapkan pola hidup sehat. Tetapi hal ini masih sulit diterapkan karena hal ini menjadi kebiasaan baru bagi masyarakat. Misalnya masih banyak yang belum mengerti bagaimana penggunaan masker yang baik dan bagaimana cara mencuci tangan yang benar Untuk itu, diperlukan edukasi yang luas ke masyarakat supaya masyarakat memiliki pegetahuan yang cukup dalam mengatasi penyebaran virus Corona.

Perilaku hidup bersih dan sehat (PHBS) adalah perilaku yang dilakukan oleh individu atas kesadaran sendiri untuk menolong dirinya di bidang kesehatan dan berperan aktif dalam bidang kesehatan (Kementerian Kesehatan, 2020). Di dalam konteks penyebaran virus Corona, penerapan PHBS ini adalah suatu cara yang paling efektif dalam mencegah infeksi dan penyebaran Virus Corona (Karo, 2020). Rajin mencuci tangan dengan sabun dengan benar, memakai masker dengan benar, mengkonsumsi makanan yang sehat, serta melakukan akivitas fisik harus disampaikan secara meluas dan gencar kepada masyarakat sebagai upaya yang efektif dalam meminimalisir penyebaran virus Corona.

Berdasarkan hal tersebut maka kegiatan ini dilakukan yaitu untuk edukasi tentang perilaku hidup bersih dan sehat (PHBS) sebagai upaya untuk meningkatkan pengetahuan masyarakat di RT 031 Kelurahan Lok Bahu Samarinda tentang upaya pencegahan penularan virus Corona yang diharapkan mampu meningkatkan kesadaran masyarakat untuk berperan dalam melakukan anjuran pemerintah untuk menanggulangi wabah ini.

\section{METODE}

Kegiatan pengabdian kepada masyarakat dengan tema "Edukasi Perilaku Hidup Bersih dan Sehat (PHBS) Untuk Mencegah Penularan Virus Corona (COVID-19) di RT 031 Kelurahan Lok Bahu Kecamatan Sungai Kunjang Samarinda" dilaksanakan pada hari Sabtu, 07 Maret 2020.

Metode pelaksanaan edukasi ini adalah dengan metode ceramah dan demonstrasi langsung tentang 
pelaksanaan cuci tangan yang baik dan benar sesuai dengan standar WHO, penggunaan masker yang benar, dan perilaku hidup bersih dan sehat sebagai upaya pencegahan penularan virus Corona. Pada kegiatan ini juga diberikan waktu untuk sesi tanya jawab sehingga masyarakat dapat menanyakan hal terkait penyebaran virus Corona ini. Untuk evaluasi kegiatan, peserta diberikan angket untuk diisi sebelum kegiatan edukasi dan sesudah diberi edukasi untuk mengetahui pengetahun peserta tentang virus Corona. Adapun materi-materi yang diberikan pada kegiatan edukasi ini adalah sebagai berikut:

1. Pengenalan tentang Virus Corona, Proses Penularan, Cara Penggunaan Masker yang Benar. Disampaikan oleh: Sister Sianturi, S.Si., M.Si.

2. Isu-Isu Terkini tentang Perkembangan informasi terkait Virus Corona dan cara akses informasi yang akurat tentang virus Corona. Disampaikan Oleh: apt.Habel Roy Sulo, M.Si.

3. Konsumsi Makanan Sehat dan Supplemen untuk Meningkatkan Sistem Imun dan Demonstrasi Cara Cuci Tangan Yang Baik dan Benar Sesuai Standar WHO. Disampaikan oleh apt.Sumarti binti Amrin, M.Si.

Tahapan Pelaksanaan

Adapun tahapan pelaksanaan kegiatan diawali dengan proses observasi atau studi awal. Pada tahap ini dilakukan penyampaian gagasan dan tujuan kegiatan kepada Ketua RT 031 Kelurahan Lok Bahu. Kegiatan studi awal ini dilakukan untuk mengetahui tanggapan dari pengurus setempat terhadap kegiatan yang ditawarkan oleh tim yang melakukan kegiatan. Pada saat studi awal ini tim pengabdian menunjukkan surat keterangan dari Lembaga Penelitian dan Pengabdian Masyarakat (LPPM) STIKES Dirgahayu sebagai bukti legalitas dari instansi yang melakukan kegiatan. Setelah Ketua RT 031 Kelurahan Lok Bahu sudah memberikan ijin kegiatan, maka selanjutnya dilakukan penyusunan jadwal kegiatan yang kemudian dilakukan kesepakatan antara tim pengabdian dengan Ketua RT 031 Kelurahan Lok Bahu yang nanti akan berpartisipasi dalam menyampaikan atau meneruskan info terkait kegiatan ini dan jadwal kegiatan kepada semua masyarakat di RT 031 Kelurahan Lok Bahu.

Pada waktu dan tempat yang telah disepakati maka masyarakat diundang oleh Ketua RT 031 Kelurahan Lok Bahu untuk mengikuti kegiatan edukasi. Acara dibuka oleh Ketua RT 031 Lok Bahu dan pembuka dari kampus STIKES Dirgahayu Samarinda yang mengadakan kegiatan pengabdian kepada masyarakat. Sebelum dilakukan edukasi, diberikan angket kepada peserta sebagai bahan evaluasi kegiatan untuk mengetahui pengetahuan peserta tentang virus Corona sebelum kegiatan edukasi dan setelah edukasi. Setelah itu diadakan penyampaian edukasi dengan metode ceramah dan domonstrasi. Sesi tanya jawab dilakukan setelah semua materi edukasi disampaikan kepada peserta dan penyampaian kesan dan evaluasi dari warga peserta kegiatan.

\section{HASIL dan PEMBAHASAN}

Kegiatan pengabdian kepada masyarakat dengan tema: Edukasi Perilaku Hidup Bersih dan Sehat (PHBS) Untuk Mencegah Penularan Virus Corona (COVID-19) ini diadakan di RT 031 Jalan Revolusi Kelurahan Lok Bahu Kecamatan Sungai Kunjang Samarinda pada hari Sabtu, 07 Maret 2020. Kegiatan edukasi ini diadakan pada saat Virus Corona sudah mulai menyebar di Indonesia tetapi belum mengalami penyebaran di Kota Samarinda. Sehingga hal ini menjadi alasan dan inisiatif pelaksana kegiatan edukasi dari 
STIKES Dirgahayu Samarinda yang terdiri dari dosen pengajar program studi S-1 Farmasi. Tujuan kegiatan ini adalah untuk melakukan edukasi kepada masyarakat yang pada saat tersebut sudah mengetahui informasi terkait penularan virus Corona tetapi masih belum paham dengan detail tentang keberadaa virus ini, cara penularannya, dan cara untuk mencegah penularan virus Corona. Kegiatan ini disambut dengan antusias oleh masyarakat yang dibuktikan dengan peserta edukasi yang cukup banyak yaitu sekitar 40 orang. Selain itu juga masyarakat terlihat sangat ingin tahu tentang virus ini yang terlihat dari peserta yang aktif dalam sesi tanya jawab karena menurut pengakuan mereka bahwa informasi yang diterima hanya sebatas informasi sekilas yang diperoleh dari media televisi atau media sosial.

Tempat diaksanakan kegiatan ini adalah di Balai Posyandu RT 031 Kelurahan Lok Bahu. Peserta yang hadir didominasi oleh kelompok orangtua dan remaja.

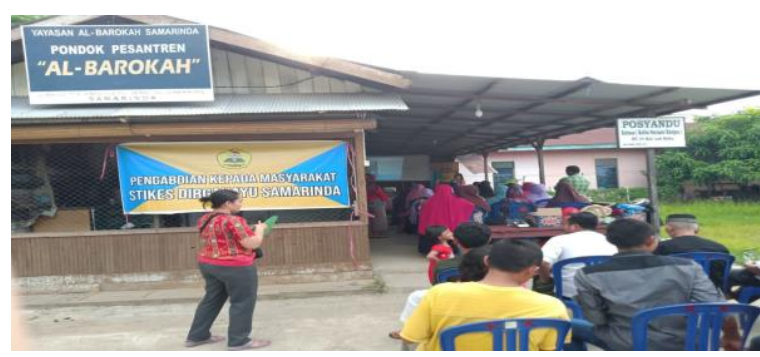

Gambar 1. Tempat pelaksanaan kegiatan edukasi di Posyandu Lok Bahu Samarinda

Peserta yang menghadiri edukasi terlebih dahulu mengisi absensi kehadiran yang disediakan oleh tim pelaksana kegiatan. Setelah itu dilakukan pembukaan edukasi yang disampaikan oleh ketua RT 031 Kelurahan Lok Bahu

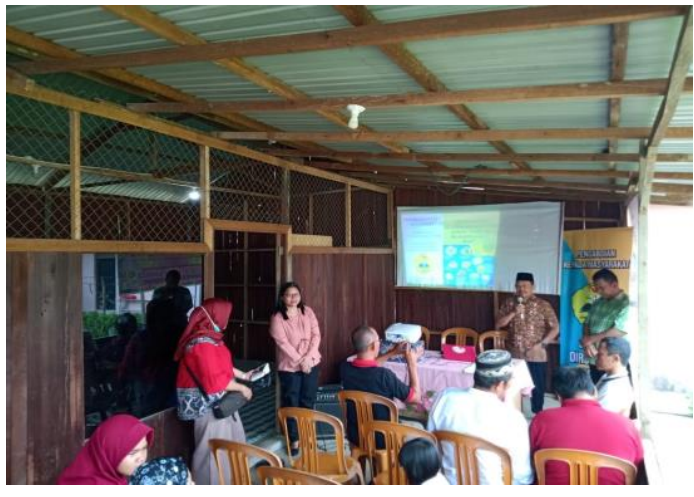

Gambar 2. Sambutan dari Ketua RT 031

Kelurahan Lok Bahu sebelum dimulai kegiatan edukasi

Selain kata sambutan dari Ketua RT, disampaikan juga kata pengantar dari tim pelaksana kegiatan yang menyampaikan gambaran kegiatan dan tujuan dilakukan kegiatan kepada masyarakat, perkenalan tim dosen yang terlibat dalam kegiatan, dan materi-materi apa saja yang akan disampaikan dalam kegiatan.

Pada kata pengantar yang disampaikan oleh tim pelaksana, disampaikan juga tentang pengisian angket kepada peserta edukasi, tujuan pengisian, dan bagaiman pengisian angket atau kuesioner tersebut

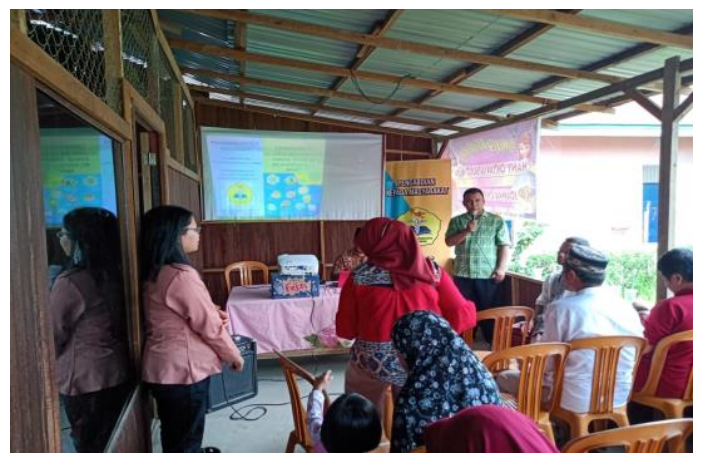

Gambar 3. Kata Pengantar dari tim pelaksana kegiatan dan penjelasan tentang pengisian angket atau kuesioner

Setelah semua peserta sudah diberikan penjelasan tentang pengisian angket maka tim pelaksana kegiatan membagikan angket tersebut untuk diisi oleh peserta. 


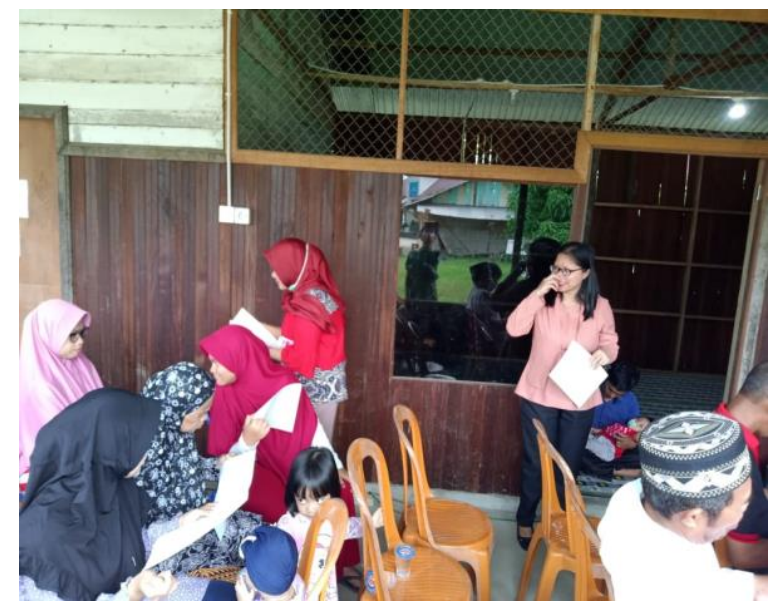

Gambar 4. Pembagian angket kepada peserta dan pengisian angket sebelum dimulai pemaparan materi edukasi

Peserta yang sudah mengisi angket dapat memberikan hasil pengisian tersebut kepada tim pelaksana kegiatan. Selanjutnya adalah pemaparan materi pertama untuk kegiatan edukasi ini yang topik utama adalah tentang pengenalan virus Corona, bagaimana siklus repsoduksi, siklus menginfeksi manusia dan hewan, cara untuk mencegah penularan virus, dan protokol penggunaan masker yang benar.

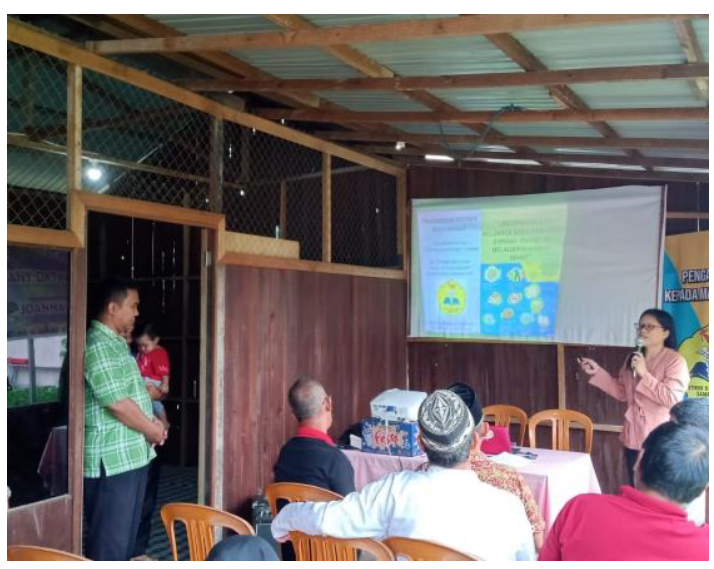

Gambar 5. Penyampaian materi pertama pada kegiatan edukasi

Kegiatan dilanjut dengan penyampaian materi kedua yaitu tentang isu/informasi terkini terkait virus Corona. Pada pemaparan ini disampaikan bagaimana cara akses informasi yang akurat sehingga masyarakat tidak mudah percaya dan membagikan informasi yang belum terbukti kebenarannya atau hoax.

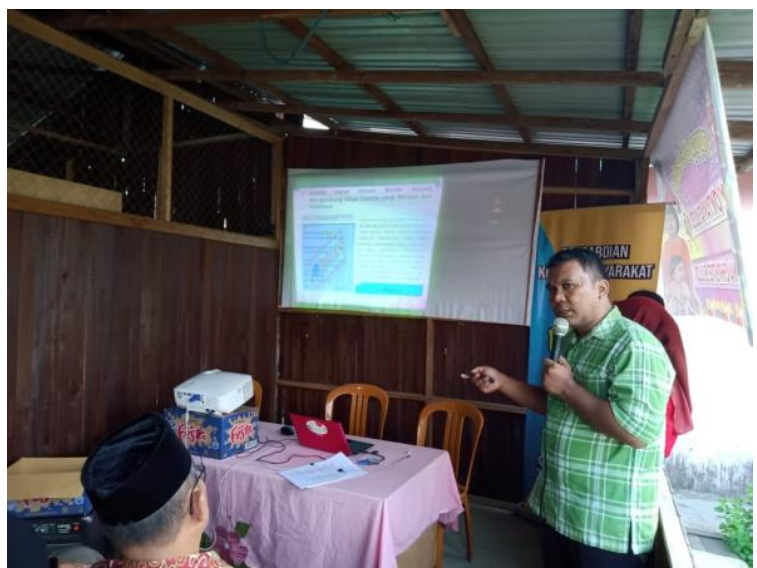

Gambar 6. Penyampaian materi kedua pada kegiatan edukasi

Penyampaian materi selanjutnya adalah tentang membiasakan pola hidup sehat dan bersih untuk mencegah penularan virus Corona. Hal ini dilakukan dengan menjaga kebersihan sekitar dan mengkonsumsi makanan yang bergizi dan suplemen makanan yang dapat meningkatkan sistem imun tubuh dalam melawan virus Corona. Pada materi ini disampaikan jenis suplemen yang direkomendasikan untuk dikonsumsi dan aturan konsumsi suplemen. Selain itu, pada materi ini juga didemonstrasikan cara cuci tangan yang baik dan benar sesuai dengan standar WHO yang ampuh dalam membunuh virus Corona.

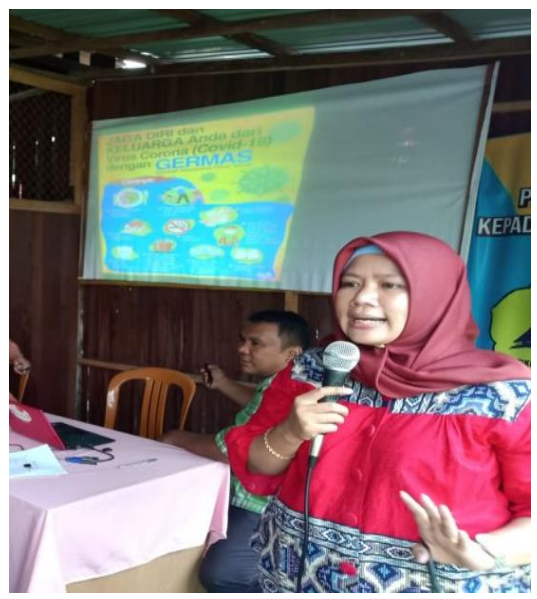

Gambar 7. Penyampaian materi ketiga pada kegiata edukasi 
Semua materi yang disampaikan kemudian dirangkum pada suatu kesimpulan penting berdasarkan masingmasing materi yang telah disampaikan. Setelah itu, diadakan sesi tanya jawab terhadap peserta yang hadir pada kegiatan untuk memberikan pertanyaan atau tanggapan terhadap semua materi tersebut. Pertanyaan dan tanggapan kemudian direspon oleh tim pelaksana kegiatan.

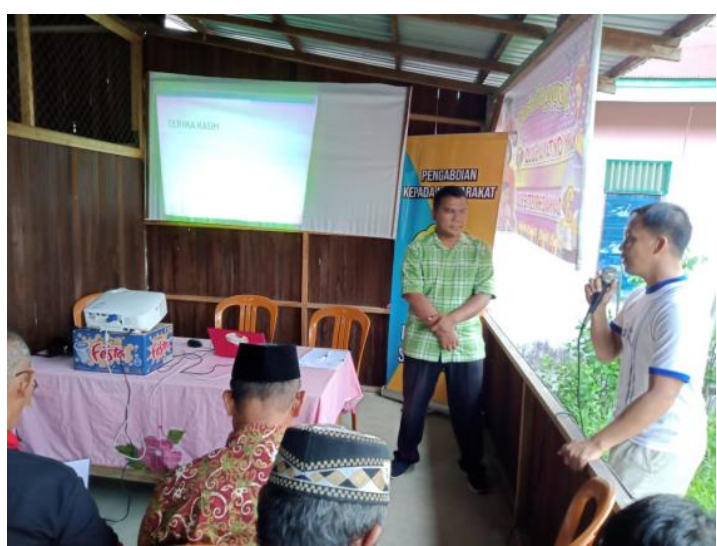

Gambar 8. Sesi tanya jawab setelah semua materi edukasi disampaikan

Kegiatan kemudian dilanjutkan dengan pengisian kembali angket kepada peserta edukasi sebagai bahan evaluasi kegiatan. Hasil evaluasi kegiatan ini menunjukkan adanya peningkatan pengetahuan peserta setelah pemberian materi yang dibuktikan dengan skor berdasarkan penilaian angket dengan nilai 50,58\% sebelum dilakukan kegiatan dan skor $89,48 \%$ setelah dilakukan penyampaian materi edukasi. Kegiatan ini juga menghasilkan respon positif masyarakat yang diindikasikan dengan tanggapan masyarakat tentang perlunya diadakan kegiatan edukasi ini secara menyeluruh.

Pada akhir kegiatan semua peserta dan tim pelaksana kegiatan edukasi melakukan sesi foto bersama.

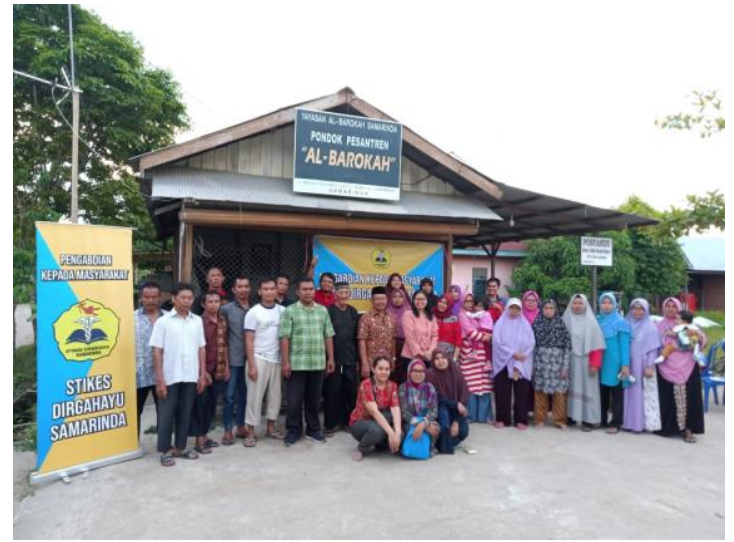

Gambar 9. Sesi foto bersama setelah kegiatan edukasi selesai

Secara keseluruhan kegiatan ini penting untuk diadakan untuk meningkatkan pengetahuan masyrakat dan membangkitkan semangat mereka untuk ikut serta dalam mencegah penularan virus Corona melalui patuh pada aturan pemerintah. Pentingnya edukasi penerapan pola hidup bersih dan sehat dapat menghasilkan masyarakat yang mampu mengenali dan mengatasi masalah sendiri serta menerapkan perilaku hidup sehat dan bersih tersebut dalam kehidupan sehari hari yang kemudian akan dicontoh oleh orang lain di sekitarnya (Notoadmodjo, 2012).

Kegiatan penyuluhan kesehatan dapat meningkatkan kesadaran masyarakat akan pentingnya menjaga lingkungan dan diri tetap sehat. Lingkungan yang sehat akan menekan perkembangan agen penyakit seperti virus dan bakteri (Sulaeman dan Supriadi, 2020)

\section{KESIMPULAN}

Kegiatan pengabdian kepada masyarakat dilakukan oleh dosen program studi S-1 Farmasi STIKES Dirgahayu Samarinda di RT 031 Kelurahan Lok Bahu Samarinda. Kegiatan berjalan dengan lancar dan mendapat respon positif dan apresiasi dari masyarakat. Evaluasi kegiatan yang 
dilakukan berdasarkan angket yang berikan kepada peserta edukasi menunjukkan adanya peningkatan pengetahuan masyarakat dari sebelum materi disampaikan dengan skor $50,58 \%$ mengalami peningkatan menjadi $89.48 \%$ setelah diberikan materi.

Saran dalam pelaksanaan kegiatan ini adalah perlu dilakukan kegiatan edukasi pada masyarakat yang lebih luas untuk mempercepat proses penyampaian informasi kepada masyarakat.

\section{DAFTAR PUSTAKA}

Karo, M.B. (2020). Perilaku Hidup Bersih dan Sehat (PHBS) Strategi Pencegahan Penyebaran Virus COVID-19. Prosiding Seminar Nasional. Hardiknas , 1-4.

Kementerian Kesehatan RI. (2020). Pedoman Pencegahan dan Pengendalian Corona Virus Disease (COVID-19) Germas, 0115.

Notoadmojo. (2012). Promosi Kesehatan dan Ilmu Perilaku. Jakarta: Rineka Cipta.

World Health Organization (WHO). (2020). Anjuran Mengenai Penggunaan Masker Dalam Konteks COVID-19. April, 1-6. 